Portland State University

PDXScholar

$5-24-2019$

\title{
The 'Girl Student' and Modernity: Imagining a Place for Women in the New Nation
}

Kayla Fish

Portland State University

Follow this and additional works at: https://pdxscholar.library.pdx.edu/honorstheses

Let us know how access to this document benefits you.

\section{Recommended Citation}

Fish, Kayla, "The 'Girl Student' and Modernity: Imagining a Place for Women in the New Nation" (2019). University Honors Theses. Paper 707.

https://doi.org/10.15760/honors.724

This Thesis is brought to you for free and open access. It has been accepted for inclusion in University Honors Theses by an authorized administrator of PDXScholar. Please contact us if we can make this document more accessible: pdxscholar@pdx.edu. 
The 'Girl Student' and Modernity: Imagining a Place for Women in the New Nation

by

\section{Kayla Fish}

An undergraduate honors thesis submitted in partial fulfillment of the requirements for the degree of

Bachelor of Arts

in

University Honors

and

History

Thesis Adviser

Ken Ruoff, Ph.D

Portland State University 
In the late nineteenth and early twentieth centuries, China underwent sweeping political and economic changes. As the multi-millennial dynastic era came to a close with the decline of the Qing, China was faced with a modern, industrial world that its massive population was scarcely equipped to handle. Increased contact with the West and Japan in the preceding centuries introduced novel elements of science, culture, and statecraft, but also brought with it a great deal of destruction to the already eroding imperial system. China found itself significantly weakened and divided by wars and confrontations, and the Middle Kingdom was displaced from its central place within its historic worldview and left spinning in the orbit of a fiercely competitive imperialist global system.

Thus, at the turn of the century, many turned to China with reformist zeal, looking to uncover what went wrong and what could be done to change the course of history. Importantly, reformers turned their attention to a previously uncovered, yet massive, portion of the population: women. Looking toward a new, modern China, for some, women represented a seemingly unlimited source of potential. But women also symbolized a major challenge to modernity, in that Chinese society would need to overcome a long-standing, deeply ingrained social hierarchy and cultural conceptions of what a woman could be.

It was in this context that the figure of the modern Chinese 'girl student' was born. Integral to the various reform projects was the ability to produce a generation of civic-minded, modern, and educated young people--doing so would in turn develop a widespread sense of belonging to the cause of national salvation. This meant introducing a modern education system, and engaging with the general population of China in unprecedented ways, including extending opportunities previously unavailable to large portions of the population. I situate my research 
within this phenomenon, where the young female student takes on the role of new national subject. I identify the late years of the Qing dynasty $(1895$ - 1911) and the early years of the Republican era (1912 - 1919) as a key period of reform. Both in last minute attempts to save the imperial system, and in forward-looking efforts to build the foundation for a modern China, these reforms increasingly pulled women into an evolving public sphere. In doing so, I delineate the extent to which developments in areas of education and print culture served to draw Chinese women into the realm of a new, unified "Chinese" identity in China's transition to modernity.

I focus on this time period not only because of the political upheaval inherent in the overthrow of the dynastic system, but because of the important shift in educational focus away from emphasis on Confucian classics and towards integrating materials of Western science and literature. New textbooks were made available to an expanded population as efforts to improve literacy were introduced, and instilled new, patriotic values in the generations that would ultimately be responsible for shaping the modern Chinese nation. Central to this change was the opening of public schools for girls, which was officially sanctioned by the Qing court in 1907, and continued into the Republican era. Education allowed women to re-define their role in modern society, but it also revealed the tensions and contradictions inherent in overcoming centuries of Confucian academic tradition, and efforts to blend Chinese tradition with new, foreign subjects. Additionally, the presence of females in schools is not only significant because they were obtaining an education, but because they were occupying what was previously strictly gendered, public space.

It it important to note that while the story of the 'girl student,' or the emerging modern woman, takes on a somewhat unique character in the circumstances of China's complicated 
journey into modernity, it is far from a unique development in the context of global social developments during this period. The early twentieth century witnessed a surge in female activism and increased public visibility for women worldwide, as women's suffrage movements progressed and images of a radical 'Modern Girl' proliferated throughout popular culture. Perhaps China's synchronous participation in this trend suggests that the country was not so out-of-step as previously thought. However, there are key elements of Chinese society that differentiate the experience of the Chinese girl student from that of her counterparts outside of East Asia, such as the cultural force of Confucianism, and the physical limitations placed on Chinese women by practices such as footbinding. Therefore, comparisons with other countries, particularly those within China's cultural sphere, such as Japan, are useful in contextualizing these developments.

Finally, I endeavor to clearly differentiate between the role of women as symbols or representations, and their lived experiences as students and educated women. While both sides of this coin are important for developing a clear understanding of what it meant to be a girl student in the early years of modern China, their significance is not necessarily congruous. It is evident that female students represented a powerful symbol of modernity, and the untapped potential of the Chinese people that could contribute to the national self-strengthening movement. However, it would be a mistake to automatically conflate this vision, expressed largely by male reformers, to the realities of women themselves. It does not necessarily tell us whether these females conceived of themselves as a fundamental part of a new Chinese nation. As such, I will make use of both contemporary textbook sources (children's primers) and print media produced for, by, 
and about young women which flourished during this period. In doing so I find powerful and often competing images of what a woman was meant to represent during this time period.

\section{Background}

Women represent a historical underclass within Chinese society. Though there are numerous female figures in pre-modern Chinese history that were exceptional in their own right, the vast majority of Chinese women remained more or less within the private sphere prior to the twentieth century. This is not to say that no women were literate or visible during this period. There did exist a tradition of women from scholar-gentry families being educated in the Confucian classics within private family schools. Literacy was considered to provide valuable moral instruction for all parts of society, and would theoretically assist in female management of the private or inner sphere. Such women produced their own literary works throughout Chinese history, and in some instances even played a hand in ruling the empire. ${ }^{1}$ More recent scholarship has also found that there was a rich literary tradition among elite female writers, known as cainü (talented women), in the late imperial period, leading historians such as $\mathrm{Hu}$ Ying to argue that women enjoyed a much more nuanced position within Chinese history. ${ }^{2}$ However, because this opportunity was available to a very small number of elite women, these women have also traditionally occupied a large part of the narrative. Indeed, even going into the twentieth century, where public educational opportunities were extended to a much broader population, the women

\footnotetext{
${ }^{1}$ Empresses and other select palace ladies represent an important exception to this rule, as they were often educated for the purpose of statecraft. There are were several key instances throughout history, including in the final years of the Qing dynasty with Empress Dowager Cixi, where women served as regents for young emperors (or even as emperor themself, in the case of Tang Empress Wu Zetian). ${ }^{2}$ Ying Hu, Tales of Translation: Composing the New Woman in China, 1899-1918 (Stanford, Calif.: Stanford University Press, 2000)
} 
who could take this opportunity remained of the upper class and thus do not reflect the experiences of Chinese women as a whole.

In the late imperial era, the tradition of educating girls and women within private family schools was directly tied to the profound influence of Confucianism in Chinese families and society at large. The established Confucian order dictated that women were subservient in most respects, be it to their sons, husbands, fathers, or emperors. However, beyond this hierarchy, there also developed a strong division of spheres between public and private, or "inner" (nei) and "outer" (wai). The place of a woman in society, and as such the things she needed to know, was strictly regulated by her mastery of this inner sphere. As the purpose of Confucian education had historically been connected to the civil examination system and ability to secure a prestigious job within the imperial bureaucracy, it offered little in terms of practical knowledge that a woman would need for running a household.

Therefore, to be a 'learned woman' in pre-modern China meant to be an upper-class women versed in Confucian classics. This had significant implications, as Confucius himself saw little value in the education of women. He is quoted as saying, "Women are indeed human beings, but they are of a lower state than men and can never attain full equality with them. The aim of female education therefore is perfect submission, not cultivation and development of the mind." ${ }^{3}$ This meant that if women could not be educated or attempt to achieve sagehood, they could at the very least be molded into the ideal Confucian female figure: a virtuous, submissive daughter, wife, and mother.

\footnotetext{
${ }^{3}$ Burton, Margaret E, The Education of Women in China, New York: (1911), 19.
} 
An important additional element of traditional Chinese education and scholarship is the strong emphasis on learning by example. In fact, imperial China had a long established tradition of producing a comprehensive history of the preceding dynasty, in large part under the belief that their successors could learn from the mistakes of past dynasties and model themselves based on seemingly effective leadership. This basic principle applies to what we can consider 'educational' texts for/on women in the pre-modern period. The earliest of such works is Lessons for Women, written by female author Ban Zhao (or "Lady Cao") in the first century CE, focused precisely on this kind of moral instruction for women. It began by stressing:

I, the unworthy writer, am unsophisticated, unenlightened, and by nature unintelligent, but I am fortunate both to have received not a little favor from my scholarly Father, and to have had a cultured mother and teachers upon whom to rely for a literary education as well as for training in good manners. ${ }^{4}$

Ban Zhao made certain to both acknowledge her lowly status through proper deference, and to point to the source of her education (or 'training'). This book is the first of what became a canonic group of four books on the instruction of women, existing parallel to the 'Four Books' in Neo-Confucianism which were the basis of education for the examination system by the later dynasties. $^{5}$

Regardless of the type of instruction outlined in these female classics, the lasting result was that a specific portion of the female population was effectively literate, and therefore had the capacity to study and engage with a variety of literature. However, there is little agreement on

\footnotetext{
${ }^{4}$ Ban Zhao, Lessons for Women

${ }^{5}$ Four Books for Women: Lessons for Women (Nüjiiè) by Ban Zhao, Women's Analects (Nǘ lúnyŭ) by Song Ruoshen and Song Ruozhao, Domestic Lessons (Nèixùn) by Empress Xu, and Sketch of a Model for Women (Nüfan jielu) by Lady Liu.
} 
the exact numbers of literate women in the pre-modern period. American scholar Margaret Burton, writing in 1911, noted that the incoming Christian missionary community had mixed opinions and questioned the practical effect of this curriculum on women. She quoted a doctor as saying "There are famous books of instruction about women... but these literary monitors seem to wield only feeble influence in real life, either over the minds of men or in moulding the lives of women." She further suggested that the reason for the education disparity came down to the social system, which made women ultimately the property of their husband's family and therefore not valuable investments to their own families. ${ }^{7}$

In discussing this background it is important to acknowledge that as the field of Chinese women's history has developed, there have been significant efforts to expand beyond the established victimization narrative and provide a more nuanced understanding of women's role. Historian Dorothy Ko argues that "From its inception, the study of Chinese women's history was integral to the nationalistic program of China's modernization," and adds that the application of Western feminist scholarship to Chinese history has only worked in congruence with a nationalist stream of thought that developed in the early twentieth century. ${ }^{8}$ She, among others, contends that the association of Chinese women with backwardness and dependency became well-established during the May Fourth - New Culture era as a way of separating the modern Chinese nation with its past.

I base my research on the understanding that women gained unprecedented access to citizenship and the public sphere in the modern era. However, the view that Chinese women

\footnotetext{
${ }^{6}$ Burton, The Education of Women in China, 20.

${ }^{7}$ Burton, The Education of Women in China, 32.

${ }^{8}$ Ko, Dorothy, Teachers of the Inner Chambers : Women and Culture in Seventeenth-Century China, Stanford, Calif. : Stanford University Press, 1994.
} 
were not inherently victims of the Confucian system is not contradictory with my thesis, which posits that Chinese women and society were essentially trained to view women as new national subjects. My question can be understood as the opposite side of this construction, which focuses on how both the minds and images of women were shaped in the process of this new national project.

\section{Political Change and Reform}

The development of modern education for women occurred continuously through the tumultuous political period of the late nineteenth and early twentieth centuries, which made it a key focus in many reform and revolutionary efforts. Rather than looking at this era in terms of political transition from the imperial system of the Qing dynasty to the early efforts of Republican government, it is useful to understand it from the perspective of ongoing intellectual and institutional development under both political systems. In the last decades of the nineteenth century, China was met with repeated threats from imperialist powers which significantly weakened its political power and cut away large 'spheres of influence.' These threats only contributed to an established pattern of dynastic decline already well underway in the Qing, as the civil bureaucracy found itself widely overextended and weakened by mass rebellions like the Taipings. Though this decline was far from an unfamiliar process in the course of Chinese history, the new presence of foreign powers likely pushed China away from the creation of a new dynasty after the overthrow of the Qing, and towards the establishment of a republic.

One important element of the late Qing reformist energy was Japan. More so than any other nation, Japan represented to China an alternative to the course of history, undergoing the 
Meiji Restoration in the nineteenth century and successfully joining the ranks of Western imperialist powers. Many Chinese reformers had a level of admiration of Japan's success, and according to historian Douglas R. Reynolds, put a high degree of faith in Japanese models. ${ }^{9}$ This was in spite of repeated conflict with Japan. While the altered power dynamic was disquieting for China, it also drew attention to how far behind they had fallen, and spurred increased zeal for implementing new models.

Reynolds argues that after 1895, three "Interrelated, mutually reinforcing developments occurred, culminating in a general "discovery" of Japan as a model for modern reform." 10 These developments were the revision of the Confucian-based education system, the organization of "study societies" by the provincial elite, and the founding of about sixty new newspapers. Numerous young scholars, who would go on to become key political and modernizing figures in the early Republican era, studied in Japan during this period and witnessed firsthand the changes the restoration had brought to Japanese society. With mounting external threats, and the continued decline of Qing power, the push for militarization and modernization only grew stronger. As Chinese reformers looked ahead to a modern nation state, modeled on foreign systems, they also sought to distance themselves from the Confucian elements of Chinese society.

\footnotetext{
${ }^{9}$ Reynolds, Douglas Robertson, China, 1898-1912: The Xinzheng Revolution and Japan, Harvard East Asian Monographs; 160. Cambridge, Mass.: Council on East Asian Studies, Harvard University: Harvard University Press, 1993.

${ }^{10}$ Reynolds, China, 1898-1912, 18.
} 


\section{Influence from Japan}

Just as Chinese reformers exhibited faith in Japanese models of industrialization, they also drew heavily on intellectual developments transmitted through Japan. This was especially the case in the aftermath of the Sino-Japanese War, when China's humiliating defeat made it all the more evident that serious measures would need to be taken for China to meet the pace of the industrialized world. While China's "Self-Strengthening” movement in the 1860-80s was focused on military modernization and industrialization in emulation of Japan, reformers at the turn of the century began to set their sights on the Chinese people. ${ }^{11}$ According to historian Limin Bai, “The adoption of new armies, technology, and political institutions was not enough to ensure the survival of China; a new kind of Chinese populace was a fundamental requirement for China to move into modernization." 12 This perspective was largely derived from readings of Japanese intellectuals, like social-Darwinist Katō Hiroyuki.

Elaborations on theories of race and social Darwinism in the late nineteenth century would form the foundation of Chinese nationalism. Japanese interpretations were particularly accessible to forward-thinking Chinese intellectuals, and offered a non-Western alternative to modernity. However, the two countries were not on equal footing. If Japan had successfully avoided imperialist advances and joined in on the race for colonies, in contrast, China was already in a semi-colonial state with its increasing number of foreign concessions. In this context, China looked at the rest of the colonized world with great fear of being permanently resigned to the global underclass. Resistance to imperialism was understood in terms of "survival of the fittest," with China on the verge of being consumed by the more "fit." In the eyes of many,

\footnotetext{
${ }^{11}$ Bai, Limin. "Children as the Youthful Hope of an Old Empire: Race, Nationalism, and Elementary Education in China, 1895-1915." The Journal of the History of Childhood and Youth 1, no. 2 (2008): 221. 12 Ibid, 213.
} 
this necessitated a complete reworking of Chinese society. The new national subject would have to be built from the ground up--patriotic education and wholesale investment in nationalism were prerequisites to modernity.

Theories on race, colonialism, and nationalism, however, were not the only intellectual ideas which Chinese reformers drew heavily upon from Japan. They also borrowed on modern understandings of gender and education for women. Writing on the Meiji state's policy towards women in the 1890-1910 period, Sharon Nolte and Sally Hastings argue that "gender construction" was a significant part of state-sponsored industrialization in Japan. ${ }^{13}$ This was articulated by the new Education Ministry in the ideal of the "Good Wife, Wise Mother," (ryōsai kenbo in Japanese, liangqi, xianmu in Chinese) which may have played on traditional rhetoric, but actually incorporated a great deal of scientific management and hygiene practices into the home.${ }^{14}$ Women were drawn into the nationalist project with the responsibility of producing strong national subjects.

In order to achieve this, women would need to be taught skills of efficient household management and transformed into productive members of society. Nolte and Hastings describe this as a "cult of productivity" as opposed to a "cult of domesticity." Curriculum for female students was centered around these skills, which directly tied the education of women to the project of modernization. At the core of this development was the Meiji state's ability to lay

\footnotetext{
${ }^{13}$ Nolte, Sharon H., and Sally Ann Hastings. "The Meiji State's Policy toward Women, 1890-1910." In Recreating Japanese Women, 1600-1945, ed. Gail Lee Bernstein (Berkeley: University of California Press, 1991) 152.

${ }^{14}$ Nolte and Hastings are careful to point out that this ideal applied only to middle/upper class women, and that they did not expect this from the working class. They also note that in Meiji Japan, working class women increasingly made up the backbone of light industry (i.e. textiles), furthering the notion that women could play a productive role in the modernization of the state. This development is mirrored in the number of Chinese women who would take up work in the cotton mills in the 20th century.
} 
claim on the family home as a public place under its own jurisdiction, and the idea that "Wives were public figures, veritable officers of the state in its microcosm, the home."15

Ultimately, the declining Qing state and its weak Republican successor did not have nearly the same capacity as Meiji Japan to exert such radical influence on Chinese society. The Meiji state was able to mandate primary school education for both genders in 1873 , after which historians note an increase from $30 \%$ of eligible females in primary schools in 1890 to over $97 \%$ by $1910 .{ }^{16}$ Clearly this program worked for its intended purposes, but it was successful because the state made it possible and strictly enforced it. Still, working in their limited capacity, Chinese reformers drew much inspiration from Japan in developing the curriculum for the increasing number of girls entering schools. While these ideas did not aim to keep women out of the public sphere, they did articulate a role for women as national subjects within preconceived notions of what a woman could do or be.

\section{Public Education for Girls}

Chinese reformers latched onto the idea that women could be trained to become modern, professional household managers. According to Paul Bailey, a deep strain of conservatism still dominated the implementation of schooling for girls. Though most reformers understood the importance of educating women in political or economic terms, they maintained socially conservative reservations regarding the place of women within the public sphere. ${ }^{17}$ Therefore, drawing from the Japanese ideal, they sought to compromise and reconfigure traditional skills to

\footnotetext{
${ }^{15}$ Nolte, Sharon H., and Sally Ann Hastings, “The Meiji State's Policy toward Women, 1890-1910," 157. ${ }^{16} \mathrm{lbid}$.

${ }^{17}$ Bailey, Paul J. "'Modernising Conservatism' in Early Twentieth Century China: The Discourse and Practice of Women's Education." European Journal of East Asian Studies 3, no. 2 (2004): 217-41.
} 
service both the family and the nation. Preferably, this meant the creation of "The well-run household in which women were to play a pivotal role by combining modern knowledge of hygiene and budgeting with traditional virtues of diligence, compliance and self-sacrifice." ${ }^{18}$ In practicality, the competing visions of the woman as both a modern, patriotic subject and a figure of traditional virtue could not be reconciled so easily, and tensions arose in its implementation.

There also existed inherent condescension in the idea of introducing 'productivity' to the lives of women. It brought with it the notion that women in their historic or traditional state were lazy, ignorant, superstitious, and "parasitically dependent." 19 In other words, the shameful current state of China could be attributed to, or at least projected onto, the backwardness of its women. Education was not just a means of realizing the full potential of women, but in the eyes of conservative reformers, also a way of undoing the damage that their own lack of productivity had caused. This produced further contradictions, as women were blamed for their limited contributions to society, yet simultaneously barred from active participation within it.

As Bailey notes, this same condescension resulted in significant anxiety over the behavior and image of women. Efforts to control and regulate this image fell particularly on female students, who represented the most visible, public discursive object during this era. Therefore, when the Qing government officially sanctioned schooling for girls in 1907, it was largely with the intent of regulating its implementation and ensuring that public schools maintained a certain moral standard. ${ }^{20}$ The physical presentation of female students was strictly regulated to avoid implications of impropriety. As opposed to new cosmopolitan styles like

\footnotetext{
${ }^{18} \mathrm{lbid}, 223$.

19 lbid, 229.

20 Bailey, "Modernising Conservatism' in Early Twentieth Century China," 225.
} 
short, bobbed hair or form-fitting clothing, the girl student was expected to remain simple and unadorned, earnestly committed to her studies and not to her appearances. Moreover, their behavior was closely monitored. Such regulation forbid girls from going unaccompanied in public, interacting with boys, or discussing politics. ${ }^{21}$ The fact that these regulations were far more specific than any regulations for boys' schools at the time is revealing.

Conservative policing of public schooling for girls suggests that Chinese society was not entirely ready to face the consequences of significant social reordering that was necessary to create a modern nation. They recognized practically that women represented a crucial population of producers and household managers (i.e. mothers). But their projection of backwardness onto women as an affliction to society can be understood as what was in reality a problem of the entire population. Additionally, the obsession over the image of these girls suggests the symbolic potency of women in the modernization project. On top of the simple practical necessity of producing a literate, productive population, the girl student had the power to project an image of exactly the kind of modernity these reformers envisioned. However, this did not always mean that women stayed in line with expectations.

\section{Curriculum and implementation}

With an understanding of the 'modernizing conservative' agenda of reformers, it is logical to then ask what the curriculum in early public schools for girls actually included. Classes at the early primarily level focused on subjects such as ethics, Chinese, arithmetic, handiwork, and physical education. At higher levels, subjects of history, geography, and science

${ }^{21} \mathrm{lbid}$. 
were added to the curriculum. ${ }^{22}$ While the mission of these schools was to cultivate patriotism amongst students of both genders, schools for girls specifically focused on virtues such as chastity, obedience, and modesty. In a According to Bailey, patriotism in female education was "Firmly linked to girls' future role as the diligent and competent maintainer of the household." 23

The industry for girls' textbooks also flourished during this time period, as publishers capitalized on the growing market of female students. Advertisements for these texts featured prominently in the emerging women's journals. For example, one page of advertisement in a 1915 issue of The Ladies' Journal (Funü zazhi) marketed a variety of books in subjects such as "Cultivating the moral character for girls," as well as "Books for study of the new national language." ${ }^{24}$ This indicates that in social areas such as morality, a distinctly gendered division was maintained to instruct on proper behavior. Meanwhile, subjects like language were considered essential for all citizens. ${ }^{25}$

A useful comparison can be drawn by looking at an early elementary primer for boys from 1913. As one of the first textbooks for young students published under the new Republican government, this text espoused patriotic lessons such as "To dedicate oneself to one's country," ${ }^{26}$ through descriptions of battles. While the goal of this text was to educate boys in a variety of modern subjects, traditional elements still permeated its lessons. This is especially the case in its depictions of women, who primarily fill roles as wives, mothers, or servants. For example, one

\footnotetext{
${ }^{22}$ Bailey, Paul J. Gender and Education in China: Gender Discourses and Women's Schooling in the Early Twentieth Century. Routledge Contemporary China Series; 15. (London; New York: Routledge, 2007). Notably, in higher primary, "handiwork" occupied as much time (six out of thirty hours per week) as history, geography, and science combined.

${ }^{23}$ Ibid, 31.

${ }^{24}$ Funü zazhi, Issue No. 11, 05 November, 1915.

25 "New national language" in this case likely refers to written vernacular Chinese, or baihuawen.

${ }^{26}$ Chudeng xiaoxue guo wenjiao keshu, Book 3 Lesson 48.
} 
lesson describes a filial daughter risking her own life to save her mother-in-law in a natural disaster, an idea that is distinctly Confucian in character. ${ }^{27}$ The lesson on the following page explains the effectiveness of modern smallpox vaccinations. This suggests that traditional Confucian morality and new Western science could seamlessly coexist, at least in these texts. Interestingly, no reference is made to female students, who would have still been particularly rare at this point.

Similarly, traditional values continued to inform the education of young women. According to Joan Judge, the idea of 'female talent and virtue,' in comparison to its nineteenth century conception of the "talented woman" (cainü), was still in the process of being defined and accepted in the early twentieth century. Judge argues that women's historical expertise in functional handiworks (such as sewing), as well as the literary prowess of women of the elite class, had to be reconfigured to fit with new societal standards of productivity. ${ }^{28}$ This serves as an important reminder to contextualize the early institution of girls' public schools within an evolving educational tradition. Many traditionally educated women, often wives of reformers and officials, played an instrumental role as educators and administrators in early schools. Paul Bailey contends that these early female reformers largely envisioned education as a means to cultivate creative talent, or as a prerequisite for social or political participation, which suggests potential contradictions with their male counterparts. ${ }^{29}$

${ }^{27}$ Chudeng xiaoxue guo wenjiao keshu, Book 5 Lesson 26. Of note: the story starts off by describing the 'Lady Lu, the wife of Zheng Yizong,' -- her husband has no relevance to the story and is not mentioned again.

${ }_{28}$ Judge, Joan, Republican Lens: Gender, Visuality, and Experience in the Early Chinese Periodical Press, (University of California Press, 2015) 149.

${ }^{29}$ Bailey, Gender and Education in China, 22. 
The earliest and most successful girls' schools actually extended on the tradition of “family learning" (jiaxue), which functioned within the established Chinese social structure. ${ }^{30}$ Progressive fathers, motivated to extend their scholarly lineages into the new-style schooling to educate their children for the modern era, established kinship-based schools for their daughters and their peers. ${ }^{31}$ This was evidently a cause taken quite seriously, as Judge notes "The dying wish of [a] patriarch of a family with many daughters, Su Mengyu, was that his five daughters would found a school." ${ }^{\prime 32}$ These schools can be understood as a mid-way point in the transition from traditional in-home learning to truly public schools, which would proliferate after the 1907 government sanctions.

Bailey suggests that the introduction of strict government regulation to public schools gave them greater legitimacy, and from that point forward they would be the most popular avenue of female education. Impersonal public schooling had the effect of decoupling young girls from their traditional place within the kinship unit. Rather than existing within the traditional life cycle of a woman through her attachments as a daughter, wife, and mother, girls were given a publicly sanctioned space to associate as individuals. This became evident in the writings of female students, where authors shirked the historical practice of signing with their father or husband's surname and birthplace by instead associating with their educational institution. $^{33}$

30 Judge, Republican Lens, 150.

${ }^{31} \mathrm{lbid}, 153$.

32 lbid, 155.

33 Judge, Republican Lens, 159. 


\section{Expectations vs. reality}

It is evident that the logistics of female education in the early twentieth century were aimed at producing a new national subject that carefully blended conservative values with the ideals of the modern nation-state. Ultimately, this came down to the contested public image of the female body, which was most clearly exemplified in the girl student. Historian Zhang Yun argues that representations of the "girl student" in the early twentieth century are significant as precursors to the "modern woman" of the May Fourth era, suggesting both a generational and an ideological link between the two. ${ }^{34}$

As such, it is important to look deeper into the potentially destabilizing character of the young female student. Previously noted obsession over the regulation of female dress and behavior continued into the early Republican era, and sustained attention to the issue suggests that students did not always maintain the ideal. Zhang suggests that despite harsh restrictions on female appearances, the girl student became the trendsetters in urban areas, taking over the role from prostitutes and courtesans. ${ }^{35}$ Most commonly, these new fashions incorporated Western styles, which prompted backlash over the flashiness and excess of the female student as a consumer. Evidently, reformers recognized the value in Western-style education, but were not always enthusiastic about its cultural influence on Chinese women.

Comparisons were commonly drawn between girl students and prostitutes, suggesting increasingly blurred lines between reputable and disreputable behavior. It is possible that prostitutes represented the most direct societal equivalent in that they were previously the most

\footnotetext{
${ }^{34}$ Zhang, Yun. "The Emerging Modern Woman: Representations of the 'Girl Student' in Early Twentieth Century Urban China." Harvard East Asia Quarterly 16, no. 3 (2014): 58.

${ }^{35}$ Zhang, "The Emerging Modern Woman," 53.
} 
visible class of women, and they too were unattached from their familial context. Furthermore, this connection makes clear how readily sexualized this new social category would become. Historian Chen Pingyuan argues that "On the surface, the proposed regulations were intended to protect fragile women from harm, but in reality they also attested to a degree of insecurity among officials about the potential consequences of male arousal." ${ }^{36}$

Furthermore, Chen's study of late Qing pictorial press argues that the image of female students was of broader concern than just for conservative reformers, pointing out that the 1907 Qing court sanctions gripped the nation's interest largely in curiosity over uniform regulations. ${ }^{37}$ One pictorial report in 1907, titled "Bu wenming!" ("Not Civilized!”), depicted men crowding the streets to observe girls leaving school in the afternoon. ${ }^{38}$ In effect, girl students did not need to do anything to draw attention or criticism, as their very act of existing publicly was provocative. Chen also suggests that this sort of voyeurism was not limited to public space, and that through the new flourishing print culture, the girl student could be observed as an exciting new cultural object from within the home. This meant exposure to female students was potentially more widespread in media than actual first-hand experience, especially outside of major city-centers.

Thus, media was significant in shaping perceptions of the female student and women in the public sphere. Pictorials, more than other forms of press, reached a wide audience of people in the lower class, and were expressly targeted at "enlightening" women and children. Unlike

\footnotetext{
${ }^{36}$ Chen, Pingyuan, "Male Gaze/Female Students: Late Qing Education for Women as Portrayed in Beijing Pictorials, 1902-08," In Different Worlds of Discourse: Transformations of Gender and Genre in Late Qing and Early Republican China, edited by Nanxiu Qian, translated by Anne S. Chao. (Netherlands: Brill, 2008): 337.

${ }^{37}$ Chen, "Male Gaze/Female Students: Late Qing Education for Women as Portrayed in Beijing Pictorials, 1902-08," 332.

${ }^{38} \mathrm{lbid}, 338$.
} 
newspapers for the educated class, these publications focused on daily life events, and showcased cultural and social ideals of the time. ${ }^{39}$ The pictorial press naturally developed an alliance with the cause of women's education due to them emerging in the same time period, as both can be considered a part of a concept known at the time as the "three weapons in the spread of civilization" (chuanbo wenming san liqi) - schools, newspapers, and public speech. ${ }^{40}$ This leads into the other important element of my thesis: print culture and media. While reformers engaged in sustained debate over women's education in this time period, we see most clearly the actual thoughts and developments of female students through periodical press.

\section{PART TWO: Women and Print Media}

Women's periodical press emerged in congruence with the opening of public schools for girls in the first decade of the twentieth century. Though a separate subject matter to education for women, the two were closely related elements of the same modernizing impulse, and were made up of largely the same groups of people. The press also brought with it a multitude of new questions regarding the place of women in a modern Chinese nation, and highlighted further the class differences inherent in the reform movement. While the aforementioned pictorial press was largely targeted at a less literate lower class, political journals and periodicals reached the upper class that was engaged in reform at the time.

The introduction of women's journals emphasized the class dynamic further, and made evident the limitations of female education in the early twentieth century. A Western-led study

\footnotetext{
${ }^{39}$ Chen, "Male Gaze/Female Students," 340.

${ }^{40} \mathrm{Ibid}, 320$. The term was coined by a Japanese, Inukai Tsuyoshi (1855-1932), but was popularized in China due to Liang Qichao's (1873-1929) interpretation.
} 
of China's female students conducted in 1917, a decade after the official sanction of schools, estimated the number of girls in school to be in the area of 170,000, while the number not in school was as high as twenty-eight million. ${ }^{41}$ Though their survey found "all grades of the social scale" to be represented in these schools, eighty-eight per cent were reported to have come from the scholar and merchant classes. ${ }^{42}$ The background of these students implies more traditional scholarly leanings, and circulation of print media among women was dependent on at least basic literacy, which limited its audience to this upper class.

\section{Language}

The issue of class and modernity played out clearly in the question of the language used in periodical press at the time. Journals had to decide between the usage of classical/literary style Chinese, or an emerging "new style" (xin wenti) writing which more closely reflecting modern Chinese vernacular. While the vernacular (baihua) favored by reformers like Liang Qichao would win out by the 1920s, at the turn of the century it was still associated with "crude" or "popular" language. A similar conflict played out in all forms of print media, as historian $\mathrm{Hu}$ Ying describes in regards to translated novels:

Each and every one of those choices carried its own specific cultural and historical implications, as well as intense personal and emotional investment on the part of individual writers. For not only did these choices constitute a writer/translator's own cultural persona as imagined by himself and others, but ultimately it was through these

\footnotetext{
${ }^{41}$ Ida Belle Lewis, The Education of Girls in China (Teacher's College, Columbia University, 1919): 41. ${ }^{42}$ Lewis, The Education of Girls in China, 47.
} 
different language choices that the late Qing intellectuals imagined the meanings of tradition and modernity. ${ }^{43}$

According to Joan Judge, most newspaper writing in this period settled upon the new style as a "linguistic hybrid" that was neither entirely speech based nor classical. ${ }^{44}$

The question of language was especially pertinent in regards to women's journals, as the implications of crudeness or disrespectability took on extreme importance with women's entering of the public sphere. Women's press struggled to portray itself as a distinctly modern and forward-looking institution, while still maintaining the legitimacy afforded by the traditional language of the elite class. Furthermore, while these journals enjoyed substantial female authorship and readership, a large portion of their audience was still reform-minded men. Media played an important role in shaping the public perception of modern Chinese women, and therefore journals sought to showcase the literary talents of women and emphasize their intellectual capabilities. $^{45}$

This suggests a complicated, and perhaps contradictory, development in female education and its relationship to modernity. Women were understood to have a lower level of literacy in classical Chinese, having largely been educated only at lower primary levels. This would necessitate a more comprehensible, modern literary style to accommodate an expanded female readership. Simultaneously, however, an image of female talent and respectability needed to be projected if women were to be accepted into the ranks of the intellectual class.

\footnotetext{
${ }^{43}$ Ying Hu, Tales of Translation: Composing the New Woman in China, 1899-1918 (Stanford, Calif.: Stanford University Press, 2000): 15.

44 Judge, Republican Lens, 20.

${ }^{45}$ Charlotte L. Beahan, "Feminism and Nationalism in the Chinese Women's Press, 1902-1911," Modern China 1, no. 4 (1975): 388.
} 
Historian Charlotte Beahan notes that contributions from female students in these journals were "Always in the most extreme formal style."46

It is difficult to ascertain how much of this tendency can be attributed to outside pressures, and how much of it came down to the literary preferences of women from a traditional scholarly background. Judge explains that "The majority of the lyrical entries published in the journal were poems $(s h i)$ in the ancient rather than the recent style (jinti shi), although some women expressed appreciation for new poetry." ${ }^{\prime 7}$ What is evident is that women were caught in the complex cross-sections of modernity and tradition, with a thin line between respectability and disrepute.

\section{Beginnings of modern Chinese print culture}

The emergence of women's journals coincided relatively closely with the development of Chinese political press. While China's indigenous print culture, seen largely in the form of gazettes, was among the oldest in the world, it took on a distinctly new character in the late nineteenth century. ${ }^{48}$ Judge attributes this evolution largely to foreign influence, arguing that print's role in political reform in the mid-to-late 1890s was heavily influenced by foreign newspapers that had operated in China throughout the nineteenth century, as they provided models and new print technology conducive to widespread circulation. Furthermore, echoing the conclusions of Reynolds in identifying the driving force behind modernization, Judge concludes

\footnotetext{
${ }^{46}$ Beahan, "Feminism and Nationalism in the Chinese Women's Press," 389.

47 Judge, Republican Lens, 21.

48 Joan Judge, Print and Politics: "Shibao" and the Culture of Reform in Late Qing China (Redwood City: Stanford University Press, 2014): 17. Early press took form in metropolitan gazettes (dibao), which represented communication between the court and provincial officials. Other types of gazette developed as time went on.
} 
that China's defeat by Japan in 1895 and the humiliating terms of the Treaty of Shimonoseki was a "Seminal event in the rise of new-style political press in China."

Outside influences that formed the foundation of Chinese political press imply that it was a medium moderated by multiple forces. This element is essential for understanding the level of freedom a publication could express in the late years of the Qing. Questions of censorship are complicated by the foreign interests operating inside of China at the time. Foreign concession zones, particularly in Shanghai, "Afforded the physical and legal space where indigenous newspapers could operate free of the threat of imperial censorship." ${ }^{50}$

The Qing court itself went back and forth on the issue of free political press during this era. During the Hundred Days' Reforms in 1898, new journals were granted legal status and gained prestige to the point of being incorporated into the examination system. However, this brief elevation was reversed following Empress Dowager Cixi's coup and the end of the first era of reforms. ${ }^{51}$ The period that followed experienced increased attention to press censorship, and the elimination of more radical political press from China proper. Modernizers like Liang Qichao and Kang Youwei fled to Tokyo, where they continued to publish within the freer intellectual environment. ${ }^{52}$

The movement of much of the intellectual community and its institutions, including political press and study societies, to Japan in the beginning of the twentieth century had the effect of producing a dual world of modernizing discourses. The reform press that continued to operate within China tended to remain within the realm of government allowance, including

\footnotetext{
49 Judge, Print and Politics, 21.

50 Judge, Print and Politics, 18.

51 lbid, 23.

52 Ibid, 26.
} 
women's journals. These publications largely advocated for reform over revolution, and sought to imagine a place for women into the Qing system. However, women's press was also inherently transgressive in the eyes of some, and at times exhibited more radical leanings.

This was the case with what Charlotte Beahan identifies as the first women's journal--in other words, the first journal produced both for and by women--Nüxue bao (Journal of Women's Studies), which was founded and edited by Chen Xie-fen in Shanghai. ${ }^{53}$ Chen was the daughter of Chen Fan, who was the owner of a radical newspaper himself, Subao, and was also involved in the administration of Shanghai's Patriotic Girls' School. This supports the suggestion that most early female educators and editors were connected to a progressive, scholarly male legacy, and further supports the strong connections between the press and education. ${ }^{54}$ Ultimately, Chen fled to Tokyo with her father in 1903 to avoid prosecution from the Qing government for Subao--at which point her publication became further radicalized. ${ }^{55}$

In contrast, Beahan discusses Peking Nübao, the only daily women's paper from this time period, which operated under the express political (and financial) support of the Empress Dowager Cixi. ${ }^{56}$ Despite the effect of being essentially an organ of Qing court news, its contents largely reflected the same enthusiasm for nationalism and modernity as other contemporary publications. This could be attributed to its Manchu Qing connections--for example, practices like footbinding were already long forbidden among Manchu women and never enjoyed state support. While anti-Manchu sentiments were mounting in this period, much of the reformers'

\footnotetext{
${ }^{53}$ Beahan, "Feminism and Nationalism," 389.

${ }^{54}$ Joan Judge, "Blended Wish Images: Chinese and Western Exemplary Women At The Turn of the Twentieth Century," NAN NÜ 6, no. 1 (2004): 104.

${ }^{55}$ Beahan, "Feminism and Nationalism," 393.

${ }^{56}$ Beahan, "Feminism and Nationalism," 408.
} 
criticism of China's 'backwardness' was actually launched at Han Chinese/Confucian traditions.

Beahan notes that “An aroused nationalistic interest in women's rights obviously crossed political lines in the early years of the century. The demand for a better life for women was not a monopoly of the opponents of the Qing government."

\section{Feminist Consciousness}

The content of late Qing and early Republican women's press reveals a great deal about the interests and concerns of the emerging class of modern educated women and girls. To be sure, male authorship and indeed male readership overwhelmed much of the early publications. The most widely circulated of late Qing women's journals, Nüzi shijie (Women's World), only featured two columns specifically for female contributions, which were generally literary, while male authors dominated the speech and editorial forums. Moreover, it has been suggested that it was a trend in this period for male contributors to use female pseudonyms, perhaps to legitimize their own prerogatives. ${ }^{58}$

To a large extent, however, works contributed by female writers reflected concerns similar to their male counterparts, or tried to elaborate on male progressive ideas with a female perspective. Aforementioned editor Chen Xie-fen, for example, drew heavy intellectual influence from Liang Qichao. Where Liang argued for the importance of moral and intellectual education, Chen added that physical education was an important basis for the other two in the

${ }^{57}$ Beahan, "Feminism and Nationalism," 410.

${ }^{58}$ Information on Nüzi shijie from the University of Heidelberg online database. https://kjc-sv034.kjc.uni-heidelberg.de/frauenzeitschriften/public/nuezi shijie/the magazine.php?magazin $\underline{i d=2}$ 
case of girls, due to their historical physical weakness. ${ }^{59}$ Notably, these ideas were expressed in magazines filled with advertisements for new medicines, such as potions said to "Improve the quality of blood, enhance and strengthen the brain and the body." ${ }^{\circ 0}$ These publications also showcased women putting modernizing constructions into action. Along the lines of the "Good Wife, Wise Mother" ideal, one 1916 issue of Funü shibao includes tips for household management and organization alongside a sample worksheet for household budgeting. ${ }^{61}$

Female contributions were often concerned primarily with elevating the nation, with an emphasis on uplifting and modernizing women so they would be fit to the task of improving the nation. For example, in 1904 one personal essay submission from a sixteen-year-old girl student in Guangdong was entitled "The establishment of women's schools should come before the promotion of equality." 62 This showcased young women actively engaging in important debates at the time, such as whether education was necessary to be granted political or social rights. While this particular student sided with the more moderate faction, others argued that "If one's education had to be the yardstick for one's rights, Chinese men were no more qualified than women." ${ }^{63}$

The question of the extent to which these publications exhibited a kind of modern Chinese feminism is difficult to resolve, because they were so closely tied to a variety of other forces (censorship, male authority, etc.). Charlotte Beahan's 1975 study concludes that heavy emphasis on female education for a strong and prosperous China was not simply a case of

\footnotetext{
${ }^{59}$ Beahan, "Feminism and Nationalism," 391.

${ }^{60}$ Funü shibao (Women's Eastern Times), Issue No. 19, 31 July 1916

$61 \mathrm{lbid}$.

${ }^{62}$ Nüzi Shijie (Women's World), Issue No. 1, 16 February 1904

${ }^{63}$ Yun Zhang, "Nationalism and Beyond: Writings on Nüjie and the Emergence of a New Gendered Collective Identity in Modern China," NAN NÜ 17, no. 2 (March 24, 2015): 256.
} 
women appealing to nationalistic interests to achieve feminist ends, but rather, women genuinely understood their concerns as an integral part of nationalist discourse ${ }^{64}$ However, more recent scholarship, alongside more modern interpretations of feminism, suggests that female writers consciously re-conceptualized the idea of womanhood in the context of nationalism, and in the process conveyed their own feminist meanings through press.

Historian Zhang Yun identifies the development in usage of the identifying term "nüjie" (women's world) as an indication of the ways in which "Women maneuvered strategically to appropriate the nationalistic discourse as they argued their own feminist agendas. ${ }^{95}$ In doing so, subtle differences in male and female usage become clearer. For example, Zhang notes that early male usage of the term included a negative connotation. Male feminists frequently lamented the position of women by drawing comparisons to slavery, but seldom attributed their condition to a specific cause, apart from the nebulous forces of history that women were unable to overcome. Meanwhile, female writers were much more likely to suggest that female subjugation was historically produced and institutionalized by men. ${ }^{66}$

Additionally, some female writers envisioned an equivalent "men's world" (nanjie), rather than conceptualizing the women's world as a separate, female-gendered alternative to the male default of society ${ }^{67}$ While both male and female writings initially focused on an ideal of women as "mothers of citizens," women gradually shifted the conversation around education to a more immediate demand for female citizenship. ${ }^{68}$ These subtle differences suggest that women

\footnotetext{
${ }^{64}$ Beahan, "Feminism and Nationalism," 412.

${ }^{65}$ Zhang, "Nationalism and Beyond," 249.

${ }^{66}$ Zhang, "Nationalism and Beyond," 273.

67 Ibid, 261.

${ }^{68} \mathrm{Ibid}, 262$.
} 
were using the same platforms with similar motivations, but did not necessarily subscribe to the male vision of women's place within the modern nation.

\section{Identity}

Closely connected with the discussion of potential feminist consciousness is the question of how women identified themselves as individuals as the result of the introduction of modern education and print media. Did these developments contribute to increased identification with women as a unique class? Zhang's argument suggests that, through the appropriation of terms like nüjie as group identifiers, women were empowered to view themselves as a unified group with specific agency. This is evident in comparison to historical terms used for women, such as funü, which historian Tani Barlow argues "Signified the collectivity of kinswomen in the semiotics of Confucian family doctrine." ${ }^{69}$ While Zhang acknowledges that the somewhat elitist nüjie fell out of favor in the 1920s with the rise of populist movements, the fact that a new classification for women independent of their family relations emerged is significant.

Still, Beahan contends that "National identification took precedence over sexual identification." ${ }^{70}$ While women were increasingly experimenting with "grouping" and expressed the need to organize cooperative societies, it seems most women were still more likely to identify as 'Chinese' before 'woman.' This was not only a result of subjection to male nationalist discourse, but also a result of increased exposure to and comparison with the rest of

\footnotetext{
${ }^{69}$ Tani Barlow, "Theorizing Women," in The Question of Women in Chinese Feminism (Durham: Duke University Press, 2004), 37.

${ }^{70}$ Beahan, "Feminism and Nationalism," 413.
} 
the world. In a study on the emergence of mass media in the early twentieth century, Leo Ou-fan Lee and Andrew J. Nathan explain that:

The intensification of communication gradually altered China's sense of space and time. More and more Chinese learned of a larger China and a wider world, if only by reading popular novels or newspapers for entertainment. They saw their region as part of a nation, their nation as a fragile entity in a threatening world, their civilization as only one among many, and not self-evidently the best. ${ }^{71}$

As such, women were constructing a modern identity in the context of an increasingly connected world. Their sense of Chinese self and Chinese womanhood could furthermore be articulated in comparison to the Western "other."

Exposure to a world beyond China meant an expanded frame of reference from which women could draw upon to understand their own status. Significant scholarship has been done on the introduction of Western figures to the established tradition of historical female exemplars. Joan Judge argues that these additions "Expanded the parameters of this highly conventionalized genre and introduced the Chinese audience to an unprecedented range of new feminine possibilities." 72 Moreover, in addition to expanded roles envisioned for women, Judge suggests that historical Chinese women were relegated to "past leaders," while modern Western heroines were seen to represent a potential "future image" of Chinese women. ${ }^{73}$

\footnotetext{
${ }^{71}$ Leo Ou-fan Lee and Andrew J. Nathan, "The Beginnings of Mass Culture: Journalism and Fiction in the Late Ch'ing and Beyond," in Popular Culture in Late Imperial China, ed. Evelyn Sakakida Rawski and David Johnson, Studies on China ; 4 (Berkeley: University of California Press, 1985): 393. 72 Judge, "Blended Wish Images," 104.

${ }^{73} \mathrm{Ibid}, 105$.
} 
However, impulses towards blending tradition with modernity still shone through. While print media commonly included stories of Western heroines, they were at times embellished with familiar Chinese tropes. For example, Zhang notes that one story presented Joan of Arc as a devoted daughter who was conflicted between serving her father or her country. ${ }^{74}$ This indicates that even in the face of nationalist concerns, Confucian ideals of filial piety could factor into an ideal modern woman's identity.

Frequently, women's publications drew direct comparisons between Western and Chinese images. This can be seen in one 1911 issue of Funü Shibao (Women's Eastern Times), which juxtaposes a photo of a traditional Chinese wedding with a portrait of a Western bride and groom. The caption describes "Preserving national essence: Chinese traditional wedding" in direct opposition to the "Sweetness of freedom: European new-style wedding." 75 The former depicts a veiled Chinese woman, surrounded by several male figures, while the latter stands proudly and unveiled beside her groom. Marriage reform represented an important part of the modernizing agenda, because practices like arranged marriage and concubinage were seen as primitive in comparison to the modern "love" or companionate marriage.

The growing tendency to draw comparisons with the West and Western women is just one example of the different futures that women (and men) were beginning to imagine for themselves in this era of immense change. Education opened a new world of opportunities, and exposure to greater possibilities through print media inspired China's young people to want more. However, it is also important to consider how the foreign 'other' is used rhetorically to define the boundaries of acceptability in this context. If the Western heroine could be used to

\footnotetext{
${ }^{74}$ Zhang, "Nationalism and Beyond," 265.

${ }^{75}$ See Figure 1. Funü Shibao (Women's Eastern Times), Issues No. 2, 26 July 1911
} 
showcase the boundless possibilities of womanhood in the modern nation-state, she could also be used to set limits or draw boundaries on what was acceptable for Chinese women. Louise Edwards argues that in mass media, even more so in the decades following our study, the apparent limitlessness of the American lifestyle was presented as the "extreme," against which “China's modern women could plot their behavior along an imagined continuum stretching between American depravity (glamorous and oh-so-romantic) and the dull prison of Confucian morality." ${ }^{\prime 76}$

Chinese feminists echoed this sentiment. For example, Tseng Pao-sun, a woman educated in missionary schools in China and then abroad, expressed reservations about the prospect of modernity 'gone too far'. In a 1931 speech titled 'Chinese Women Past and Present", Tseng notes:

It is out of this melting pot that the Chinese woman is trying to emerge as a new being. She is at a cross roads; it is difficult to say which road she will take. Will she revert to the old as the pendulum swings back? Or will she throw over all her heritage and become a totally new person, unknown to her land, and alien to her civilization? Or will she retain what is best in China and supplement it with the best from the West? The third possibility is naturally what we want. ${ }^{77}$

For most women, limits could only be tested to a certain extent. Even the most radical of women were still bound by the society they lived within. The previously mentioned editor Chen Xie-fen, only narrowly avoided becoming a concubine to her progressive father's friend. ${ }^{78}$

\footnotetext{
${ }^{76}$ Louise P. Edwards, “The Shanghai Modern Woman's American Dreams: Imagining America's Depravity to Produce China's 'Moderate Modernity'” 81, no. 4 (2012): 568. ${ }_{77}^{7}$ Yu-ning Li, Chinese Women through Chinese Eyes (New York: Routledge, 2015), 85.

${ }^{78}$ Beahan, "Feminism and Nationalism in the Chinese Women's Press, 1902-1911," 384.
} 
Moreover, people from all directions expressed concern over how to practically incorporate this new generation of educated girls and women into a modern nation.

In the previously mentioned study of Chinese girls' education from 1917, Ida Lewis concludes by expressing concern over what the future held for these women. In their survey of 661 female students, the vast majority of responses indicated that girls envisioned themselves in public professions--even in the limited capacities available to them. This included careers such as teachers or nurses, as well as aspirations for higher education. Many respondents expressed uncertainty over the future, and only one indicated her primary desire to be within the home. ${ }^{79}$ Such visions were the source of significant discomfort among progressives and conservatives alike. Not only did a turn away from domestic responsibilities represent a threat to the established foundation which society was built upon, but it also seemed unrealistic in the context of the limited roles actually available to women.

Lewis warned that "Educators will need to guard against desocialization of the girls while in school, and to direct their attention to the strengthening of the bonds between the school and home community life. ${ }^{\circ 0}$ Tseng Pao-sun expressed similar concerns that Chinese schoolgirls would feel "So burdened with national and social welfare that she should devote herself entirely to these and live a single life." ${ }^{81}$ Elisabeth Croll, in a study of the changing identities of Chinese women, suggests that educated girls increasingly chafed at domestic confinement. ${ }^{82}$ Evidence overwhelmingly suggests that girls, under the influence of a modern

\footnotetext{
${ }^{79}$ Lewis, The Education of Girls in China, 54.

${ }^{80}$ lbid, 51.

${ }^{81} \mathrm{Li}$, Chinese Women through Chinese Eyes, 83.

82 Elisabeth Croll, Changing Identities of Chinese Women: Rhetoric, Experience, and Self-Perception in Twentieth-Century China (Hong Kong: London; Atlantic Highlands, N.J.: Hong Kong University Press; Zed Books, 1995), 43.
} 
education, were poised to reject the restrictions placed on them by traditional society--yet in most cases they lacked the capacity (or economic opportunity) to do so.

Moreover, an increased significance placed on medical science and human biology within the modernization movement sought to define and outline a place for women in scientific terms which upheld the traditional gender hierarchy. According to Frank Dikötter:

Social roles of women and men were now thought to be grounded in nature: bodies dictated different but complementary social roles, not imperial cosmology. Biological distinctions between male and female, which rarely assumed a primary function in imperial China, became essential. Modernizing discourses appealed to science. ${ }^{83}$

Fighting against the traditional hierarchy was one thing, but fighting against the new scientific standard was another.

Furthermore, girl students were at a particularly important juncture in this period. Not only did they represent the entrance of women into the public sphere, but their young age granted them status as 'youths' in a period where this age group was taking on special importance. Dikötter points out that young people experienced a rapid rise in social status and political power during this time period. Classification as a 'young adult' had previously been limited to men, as women were considered of marriageable age upon reaching sexual maturity. The concept of youth being extended to women was significant in a time where "'Youth' was also turned into a powerful symbol of regeneration, vitality and commitment to modernity: it was invented as standing for reason, progress and science." ${ }^{\prime 4}$ Therefore, both the gender and the age of the girl student was of great significance in figuring their modern identity.

\footnotetext{
${ }^{83}$ Frank Dikötter, Sex, Culture, and Modernity in China: Medical Science and the Construction of Sexual Identities in the Early Republican Period (Honolulu: University of Hawaii Press, 1995), 20.

${ }^{84}$ Dikötter, Sex, Culture, and Modernity in China, 147.
} 
This combination of developments produced an atmosphere where women had both unprecedented opportunity and pressure. One pressure was to uphold and maintain Chinese civilization--Tamara Hamlish's discussion of women's role in the construction of modernity is instructive here. Hamlish argues that in such projects, women find their lives and experiences readily "Reduced to instances of the successes and failures of modernity, or to quaint exotica in the culture gardens of tradition." 85 Crafting a modern identity in the cross-fire of these competing forces proved difficult.

\section{Looking Forward}

Leading into the modern era, China still faced an uncertain political future. The newly established Republic quickly fell into the hands of a new dictator, Yuan Shikai, who declared himself emperor by 1915. From this point forward, control of China was largely split among competing warlords. In this context, institutional change that would allow for a more pronounced role for women in the public sphere was impossible. Moreover, revolutionary energy moved increasingly in the direction towards a form of nationalism that de-emphasized the importance of women's issues in a grander scheme of nation-building.

For the remainder of my thesis I will project somewhat beyond the era where I have focused my study, which I identify as the key period in which modern education for girls and women's press emerged. In doing so I will briefly attempt to assess how the aforementioned factors played out in the context of political and intellectual developments. In doing so, I evaluate what place the young Chinese woman occupied in this new Chinese nation. This

\footnotetext{
${ }^{85}$ Tamara Hamlish, "Calligraphy, Gender, and Chinese Nationalism," in Gender Ironies of Nationalism: Sexing the Nation, ed. Tamar Mayer (London ; New York: Routledge, 2000), 213.
} 
progression is significant, because many of the active female participants came of age in the context of this modern education, and their understanding of modernity was shaped by the media previously discussed.

Historian Louise Edwards, in an assessment of the women's suffrage movement in China, defines the first wave of suffrage as having died in 1912. In this year, the women failed to obtain equal political rights and representation in the new national parliament. According to Edwards, "The parliamentarians told the women to 'go and get educated about politics' and once this was achieved they could return to press the case for a constitutional amendment." 86 This advice proved ineffectual, as the new constitution and parliament would collapse within two years and China would soon find itself under the tenuous control of another despot. The discourse of education as a precursor to political participation appears here repeatedly. Moreover, Edwards emphasizes that the campaign for equality was too submersed the nationalist rhetoric of the anti-Qing/pro-Republican movement to generate actual results for women. ${ }^{87}$

Much modern gender scholarship bases itself on the assumption that nationalism is harmful to feminist movements, as the goals of women (or other minorities) get subsumed in the larger cause, indefinitely put off or lowered in priority. There have been challenges to this assumption, particularly in the context of post-colonial or Third World nationalism, as has been argued by Hee-Kang Kim. ${ }^{88}$ In the context of early Republican China, however, the opposition of feminism and nationalism seems to support traditional assumptions. Edwards identifies the next

\footnotetext{
${ }^{86}$ Louise P. Edwards, "Chinese Women's Campaigns for Suffrage: Nationalism, Confucianism and Political Agency," in Women's Suffrage in Asia Gender, Nationalism and Democracy, ed. Mina Roces, Routledge Studies in the Modern History of Asia; 16 (London; New York: Routledge, 2004), 62. ${ }^{87}$ Ibid, 63.

${ }^{88}$ See Hee-Kang Kim, "Should Feminism Transcend Nationalism? A Defense of Feminist Nationalism in South Korea," Women's Studies International Forum 32, no. 2 (2009): 108-119.
} 
wave of women's suffrage activity as occurring in the period surrounding the May Fourth and New Culture movements (1915-1925).

The New Culture Movement and its relationship with women is worthy of examination, because it in many ways encapsulates this problem. This movement and its emphasis on youth (which I have discussed previously) focused on issues that would have been most pertinent to young women, yet its tendency towards male leadership resulted in detractions from women's rights efforts. For example, one of its key focuses was family reform, an issue seemingly essential to determining how women would factor into the envisioned 'New China.' However, as Susan Glosser explains, "The primary impetus of the family revolution was the search of young, urban males for a new identity in a modernizing, industrializing society." ${ }^{89}$ As such, it was largely motivated by social and economic factors relevant to young men.

Though these New Culture intellectuals sought to radically restructure the family and its links between the individuals and the state, they echoed aforementioned concerns of women straying too far from their historical place as wives and mothers. They challenged Confucian authority in the form of the patriarch, but repeatedly ignored or downplayed the role of women in the family structure as merely powerless victims. ${ }^{90}$ In their re-imagining of the family from a traditional patriarchal structure to a new ideal of "companionate marriage," young men had a tendency to place additional expectations on women, rather than change their expectations. Ideal women were now imagined as both educated and intelligent companions to men, and as nurturing mothers and homemakers. Moreover, discussions of what constituted the "ideal husband" were exceedingly rare.

\footnotetext{
${ }^{89}$ Susan L. Glosser, Chinese Visions of Family and State, 1915-1953, Asia--Local Studies/Global Themes; 5 (Berkeley: University of California Press, 2003), 27.

${ }^{90}$ Glosser, Chinese Visions of Family and State, 1915-1953, 42.
} 
Women who did join the ranks of the revolutionaries in this time period tended to play up their nationalistic goals over feminist ones. The mark of a proper modern woman was in large part her willingness to sacrifice her own desires for the national cause. Sarah Stevens argues that the terms "New Woman" (xin nüxing) and "Modern Girl" (moudeng gou'er), though often used interchangeably in this context by historians, actually served distinctly different rhetorical functions in literature from this era. ${ }^{91}$ The archetype of the New Woman was seen to represent modernity at its best; showcasing the strength and progress of Chinese civilization. Meanwhile, the Modern Girl, cosmopolitan and self-assured, contained all of the anxieties of modernity, including alienation and loss of culture. ${ }^{92}$ The deceptively similar nature of these two figures (they took on most of the same physical attributes) emphasizes the apprehensions surrounding women.

The mounting Communist movement in China in the 1920s makes clear the shift in prioritization of women's issues. As education for girls was limited to such a miniscule, elite class, feminism in their terms quickly lost favor to more populist visions of modernity. The ideal of gender equality under Communism allowed revolutionaries to further de-emphasize the individual goals of women in the name of a greater political cause. While the further development of China's Communist movement and full-scale military confrontations in the 1930s and 1940s are beyond the scope of this study, it is important to contextualize the new role for women in modern China. Expanded education and literacy afforded Chinese women a definite space within the social framework of the new nation-state. The ideal New Woman, who

\footnotetext{
91 The "Modern Girl" corresponds directly with Western and Japanese images of the figure. ${ }^{92}$ Sarah E. Stevens, "Figuring Modernity: The New Woman and the Modern Girl in Republican China," NWSA Journal 15, no. 3 (2003): 83.
} 
would readily discard her selfish femininity in the name of revolutionary modernity, was still intensely political, nationalistic, and intelligent as a result of her modern upbringing.

\section{Conclusion}

In this project I have focused on the main influences which young girls were exposed to in the early stages of Chinese modernity. The introduction of a modern public education system for children went hand in hand with the introduction of new political and intellectual ideals in China. Thus, education and media functioned as powerful tools in inculcating nationalistic images of modernity. Chinese women, as a historical underclass that had a limited presence in the public sphere, encountered an ever-growing number of possibilities and expectations of them in a radical new context. A limited number of girl students occupied spaces previously restricted to them, and in the process carved out an individual identity for women which was independent of kinship relations. As a result, their image functioned as a powerful symbol of modernity, which the hopes and fears of the Chinese nation could be projected onto. Expanded roles for women drew on ideals from the West and Japan to construct the modern Chinese woman against the foreign other. Meanwhile, wielding their new education and a popular platform through print media, women increasingly engaged in modernizing discourse that would help shape the new nation and their role within it.

Tensions between tradition and modernity also found their focus in the 'woman question,' as reformers and modernizers sought to figure a place for women that would contribute productively towards nation-building without sacrificing their fundamental role in reproduction and household management. In this tension, the growth of female possibilities 
coincided with an expansion of societal pressures and expectations. Women responded to these expectations in a large capacity as a result of their own personal investment in the modernization project. They consistently prioritized their national identity over their gender, while attempting to figure their own desires into this framework. 
Fish 41

Figure 1: Comparison of Western and Chinese style weddings
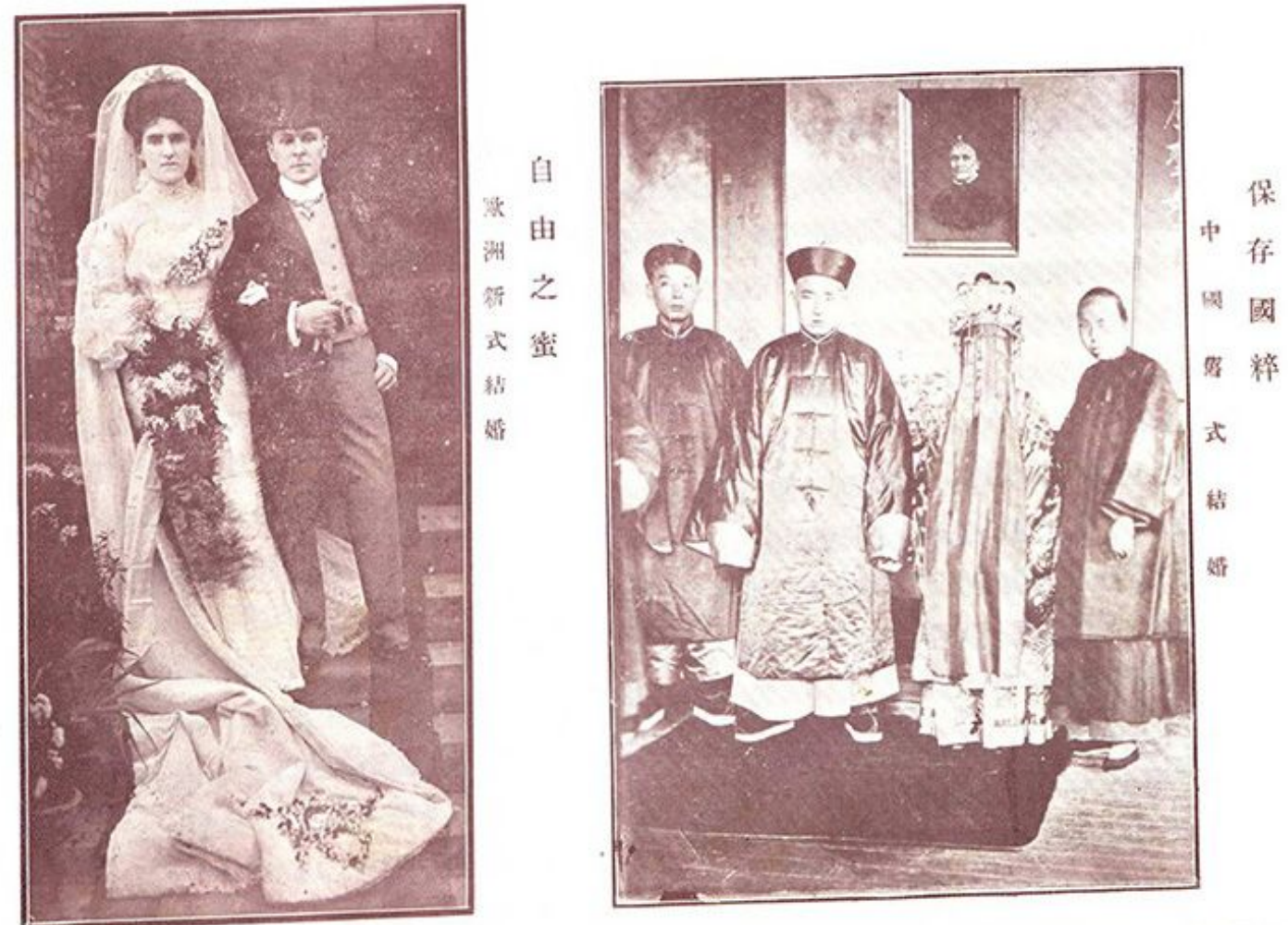

(C) Courtesy of the Institute of Chinese Studies, Library, Heidelberg University. 


\section{Bibliography}

Bai, Limin. 2008. "Children as the Youthful Hope of an Old Empire: Race, Nationalism, and Elementary Education in China, 1895-1915." The Journal of the History of Childhood and Youth 1 (2): 210-231.

Bailey, Paul J. 2004. “'Modernising Conservatism' in Early Twentieth Century China: The Discourse and Practice of Women's Education.” European Journal of East Asian Studies 3 (2): 217-41.

- 2007. Gender and Education in China: Gender Discourses and Women's Schooling in the Early Twentieth Century. Routledge Contemporary China Series; 15. London ; New York: Routledge.

Barlow, Tani. 2004. "Theorizing Women.” In The Question of Women in Chinese Feminism, 37-48. Durham: Duke University Press.

Beahan, Charlotte L. 1975. "Feminism and Nationalism in the Chinese Women's Press, 1902-1911.” Modern China 1 (4): 379-416.

Burton, Margaret E. 1911. The Education of Women in China. Fleming HRevell,. Chen, Pingyuan. 2008. "Male Gaze/Female Students: Late Qing Education for Women as Portrayed in Beijing Pictorials, 1902-08." In Different Worlds of Discourse: Transformations of Gender and Genre in Late Qing and Early Republican China, edited by Nanxiu Qian, translated by Anne S. Chao. Netherlands: Brill.

Croll, Elisabeth. 1995. Changing Identities of Chinese Women: Rhetoric, Experience, and Self-Perception in Twentieth-Century China. Hong Kong : London ; Atlantic Highlands, N.J.: Hong Kong University Press; Zed Books.

Dikötter, Frank. 1995. Sex, Culture, and Modernity in China: Medical Science and the Construction of Sexual Identities in the Early Republican Period. Honolulu: University of Hawaii Press.

Dorothy, Ko. 1994. Teachers of the Inner Chambers : Women and Culture in Seventeenth-Century China. Stanford, Calif. : Stanford University Press.

Edwards, Louise P. 2004. “Chinese Women's Campaigns for Suffrage: Nationalism, Confucianism and Political Agency." In Women's Suffrage in Asia Gender, Nationalism and Democracy, edited by Mina Roces. Routledge Studies in the Modern History of Asia; 16. London; New York: Routledge. 
—. 2012. “The Shanghai Modern Woman's American Dreams: Imagining America's Depravity to Produce China's 'Moderate Modernity'” 81 (4): 567-601.

Glosser, Susan L. 2003. Chinese Visions of Family and State, 1915-1953. Asia--Local

Studies/Global Themes ; 5. Berkeley: University of California Press.

Hamlish, Tamara. 2000. “Calligraphy, Gender, and Chinese Nationalism.” In Gender

Ironies of Nationalism: Sexing the Nation, edited by Tamar Mayer. London ; New

York: Routledge.

Hu, Ying. 2000. Tales of Translation: Composing the New Woman in China, 1899-1918.

Stanford, Calif:: Stanford University Press.

Judge, Joan. 2014. Print and Politics: "Shibao" and the Culture of Reform in Late Qing

China. Redwood City, United States: Stanford University Press.

- 2015. Republican Lens: Gender, Visuality, and Experience in the Early Chinese

Periodical Press. University of California Press.

—. 2004. "Blended Wish Images: Chinese and Western Exemplary Women At The

Turn of the Twentieth Century." NAN NÜ 6 (1): 102-135.

Lee, Leo Ou-fan, and Andrew J. Nathan. 1985. "The Beginnings of Mass Culture:

Journalism and Fiction in the Late Ch'ing and Beyond." In Popular Culture in Late

Imperial China, edited by Evelyn Sakakida Rawski and David Johnson. Studies on

China ; 4. Berkeley: University of California Press.

Lewis, Ida Belle. 1919. The Education of Girls in China. Teacher's College, Columbia University.

Li, Yu-ning. 2015. Chinese Women through Chinese Eyes. New York: Routledge.

Nolte, Sharon H., and Sally Ann Hastings. 1991. "The Meiji State's Policy toward Women, 1890-1910.” In Recreating Japanese Women, 1600-1945, by Gail Lee Bernstein, 151-74. Berkeley: University of California Press.

Rawski, Evelyn Sakakida. 1979. Education and Popular Literacy in Ch'ing China.

Michigan Studies on China. Ann Arbor: University of Michigan Press.

Reynolds, Douglas Robertson. 1993. China, 1898-1912: The Xinzheng Revolution and Japan. Harvard East Asian Monographs ; 160. Cambridge, Mass.: Council on East Asian Studies, Harvard University: Harvard University Press.

Stevens, Sarah E. 2003. "Figuring Modernity: The New Woman and the Modern Girl in Republican China." NWSA Journal 15 (3): 82-103. 
Zhang, Yun. 2014. "The Emerging Modern Woman: Representations of the 'Girl Student' in Early Twentieth Century Urban China." Harvard East Asia Quarterly 16 (3): 50-59. . 2015. "Nationalism and Beyond: Writings on Nüjie and the Emergence of a New Gendered Collective Identity in Modern China." NAN NÜ 17 (2): 245-75. 